\title{
10. Geothermal potential of granitic rocks of the Mourne Mountains
}

\author{
Mohammednur Desissa Ture, ${ }^{\mathrm{I}}$ Derek Reay, ${ }^{2}$ Mark \\ Muller, ${ }^{3}$ Chris Yeomans ${ }^{4}$ and Laura Ayres ${ }^{5}$
}

How to cite this chapter:

Ture, M.D., Reay, D.M., Muller, M.R., Yeomans, C.M. and Ayres, L.A., 2016

'Geothermal potential of granitic rocks of the Mourne Mountains' in M.E. Young (ed.), Unearthed: impacts of the Tellus surveys of the north of Ireland. Dublin. Royal Irish Academy.

DOI:10.3318/ 978-1-908996-88-6.ch10
The Palaeogene Mourne Mountains Complex in County Down is a potential geothermal energy resource due to the high levels of radioactivity in its granitic rocks. The regional Tellus geochemical and geophysical surveys mapped the radioelement distribution of the rocks at surface. Follow-up investigations confirmed the heat potential of these, some of the most radioactive rocks in the island of Ireland, and investigated their depth extent by electromagnetic (magnetotelluric, MT) depth sounding. The results suggest that resistive rocks, interpreted as the granitic intrusion, reach depths of 5 to $6 \mathrm{~km}$ in the Eastern Magmatic Centre and 4 to $5 \mathrm{~km}$ in the Western Magmatic Centre. The MT results are discussed in the context of the different models of granite emplacement proposed for the Mournes.

Tellus aeromagnetic data and MT modelling suggest that the granite bodies extend at depth to the south of the outcrop, as predicted for the laccolith emplacement mechanism, although modelled granite thickness is greater than expected. The MT data indicate a high-conductivity zone of unknown origin beneath the granites, extending from depths of 8 to $20 \mathrm{~km}$. The high radiogenic heat production and the modelled thicknesses of granites are favourable factors for the enhanced geothermal system (EGS) potential of the Mournes, although the measured geothermal gradients and calculated heat flows are lower than those in comparable EGS targets.

\section{THE SCOPE FOR GEOTHERMAL ENERGY IN IRELAND}

Geothermal energy is energy stored in the form of heat beneath the surface of solid earth. Assuming an average worldwide geothermal gradient of $25^{\circ} \mathrm{C} \mathrm{km}^{-1}$, it is simple to calculate that $99.7 \%$ of the Earth is at a temperature greater than $150^{\circ} \mathrm{C}$. Clearly the heat resources

\footnotetext{
${ }^{\mathrm{I}}$ Geological Survey of Ireland, Dublin.

${ }^{2}$ Geological Survey of Northern Ireland, Belfast.

${ }^{3}$ Dublin Institute for Advanced Studies.

${ }^{4}$ Camborne School of Mines, University of Exeter; British Geological Survey, Keyworth.

${ }_{5}$ University of Birmingham.
} 
of the Earth are vast. However, the engineering challenges of heat extraction are great and the capital costs and geological risks high, so there has to date been little incentive to invest in the development of geothermal energy, compared with other low-carbon energy resources. Nevertheless, in the future, as the use of fossil fuels declines and technology develops, the scope for wider exploitation of geothermal resources can only increase.

Extracting geothermal energy from readily accessible shallow heat reservoirs in volcanically active regions is well established, notably for example in Iceland. In less active regions, such as the UK and Ireland, there is also scope for exploiting geothermal resources from two principal categories. Firstly, in hot sedimentary aquifers (HSAs), naturally occurring hot water in sedimentary strata is pumped to the surface to feed district heating networks or, if hot enough, to generate electricity. An HSA system has been running successfully for district heating in Southampton since 1987, and the method could be used in other areas. HSA targets in Northern Ireland have been identified from geophysical surveys and deep boreholes in the Larne, Lough Neagh and Rathlin sedimentary basins.

Secondly, in EGSs cold water is injected from surface into a zone of fractured hot rock, where it is circulated and heated before being pumped to surface, usually to drive a power station turbine. In the UK and Ireland, such hot rock reservoirs appropriate for EGS may exist in several intrusive granite bodies (known as high heat production (HHP) granites) in which heat is produced by natural radioactive decay. A UK deep geothermal energy research programme in the 1980s, jointly funded by the EC and the UK government, included drilling and fracturing the radioactive Carnmenellis granite in Cornwall. Follow-on developments from this earlier programme include two proposed power plants in Cornwall.

The geological potential and economic implications of development of geothermal targets in Britain and Northern Ireland have been widely reported; reviews include those by Kelly et al. (2005), Busby (2010), Pasquali et al. (2010), GT Energy (2011) and SKM (2012). Similar assessments for the Republic of Ireland have been made by Goodman et al. (2004, 2010), Jones et al. (2010) and Pasquali et al. (2015). Several sites in Northern Ireland and the Republic of Ireland are the subject of geological and geophysical research by the IRETHERM project (www.iretherm.ie) led by the Dublin Institute of Advanced Studies (DIAS).

The Tellus and Tellus Border Projects, through a limited programme of ground surveys, drilling and analysis, examined the EGS potential of the Mourne Mountains Complex, County Down. In the Tellus and Tellus Border survey areas other less radioactive granite bodies that may in the future offer scope for EGS are the Cooley Mountains, County Louth; the Ox Mountains, County Sligo; and the County Donegal granites.

\section{ENHANCED GEOTHERMAL SYSTEMS AND HEAT PRODUCTION}

The flow of heat from the Earth's interior to the surface has two components: primordial heat released by the cooling down from the Earth's formation, and radiogenic heat produced by the decay of radioactive isotopes in the mantle and crust. Most crustal 
rocks contain small concentrations of the radioactive isotopes of uranium $\left({ }^{238} \mathrm{U},{ }^{235} \mathrm{U}\right)$, thorium $\left({ }^{232} \mathrm{Th}\right)$ and potassium $\left({ }^{40} \mathrm{~K}\right)$, but in some granite bodies the concentrations may be anomalously high. These HHP granites typically have elevated radiogenic heat production rates that can be estimated from the measured concentrations of the heat-producing radionuclides. Such measurements can be made locally by geochemical analyses of rock samples or by ground gamma-ray spectrometry and regionally by airborne gamma ray spectrometry (AGRS).

Using current EGS technology, water temperatures of $100-150^{\circ} \mathrm{C}$ are needed for electricity generation and so the target depth in stable continental settings is usually between 3 and $5 \mathrm{~km}$, depending on the local geothermal gradient. Key parameters for assessing EGS potential are heat flow, heat production, the depth and extent of the granite and its capacity to be fractured.

\section{Thermal characteristics of granites in the UK and Ireland}

Busby (2010) has summarised the research of the past 30 years into the thermal characteristics of UK rocks. The average background crustal heat flow for the British Isles is approximately $52 \mathrm{~mW} \mathrm{~m}{ }^{-2}$. Radiogenic granites in Cornwall $\left(113-126 \mathrm{~mW} \mathrm{~m}^{-2}\right)$, the Pennines $\left(78-101 \mathrm{~mW} \mathrm{~m}^{-2}\right)$ and the Eastern Highlands of Scotland $\left(59-76 \mathrm{~mW} \mathrm{~m}^{-2}\right)$ all show above-average heat flows. Wheildon et al. (1985) calculated values of 84-87 mW $\mathrm{m}^{-2}$ in two boreholes in the Mourne Mountains Complex, after topographic and palaeoclimate corrections, although these boreholes were relatively shallow (66 m and $149 \mathrm{~m}$ total depth). Downing and Gray (1986) indicate (their Fig. 10.1) that the Mournes area is one of only three areas in the UK where a temperature of $200^{\circ} \mathrm{C}$ may be encountered at depths of less than $7 \mathrm{~km}$, although the geothermal gradients may have been overestimated by these authors.

Systematic research into the radiogenic heat potential of granites in Ireland has been carried out by scientists at NUI Galway, funded by EC and government grants. These quantitative studies into the radioelement abundances of granite batholiths in County Galway (Feely and Madden, 1986, 1987, 1988; Feely et al., 1991; Madden, 1987), Leinster and Donegal (McCabe, 1993) were based largely on extensive ground surveys using portable gamma-ray spectrometers, augmented by measurements made in shallow boreholes. Of these Caledonian granites, the small Costelloe Murvey leucogranite in the Galway batholith had the highest calculated heat flows $\left(72-79 \mathrm{~m} \mathrm{~W} \mathrm{~m}^{-2}\right)$ and heat production estimates $\left(5.0-7.83 \mu \mathrm{W} \mathrm{m}^{-3}\right)$.

This research also characterised the Barnesmore granite in County Donegal as HHP granite, and this has been confirmed by both the Tellus Border AGRS data and Willmot Noller et al. (2015), who determined a mean production of $3.11 \mu \mathrm{W} \mathrm{m} \mathrm{m}^{-3}$ from existing data. Cook and Murphy (1952) estimated that the Barnesmore granite was about $5 \mathrm{~km}$ thick, based on simple 2D gravity modelling. Elsewhere, the Tellus Border stream sedi- 


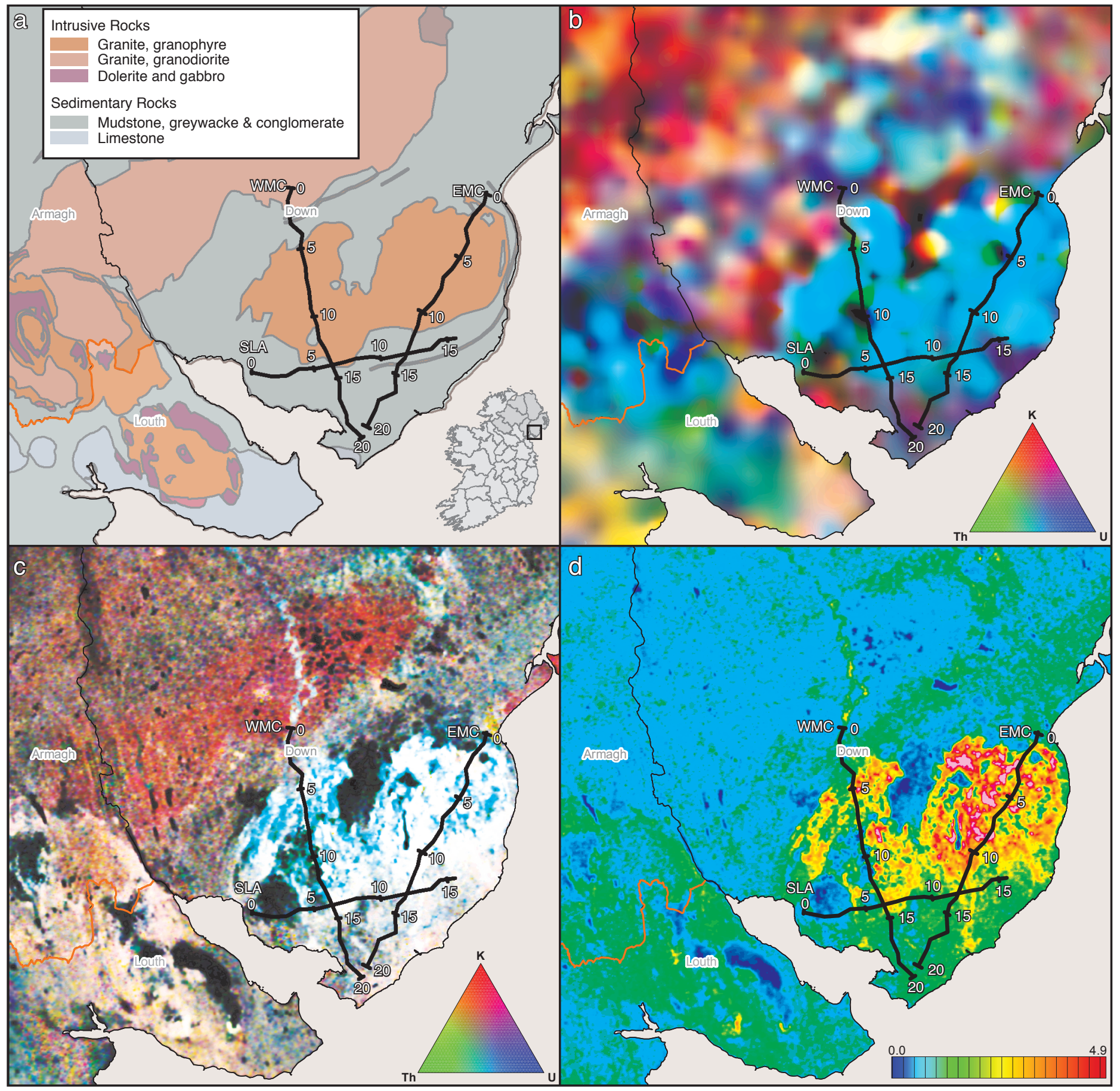


Figure 10.1. The Mourne Mountains Complex: (a) geology; (b) ternary image of soil U, Th and $\mathrm{K}$; (c) ternary image of AGRS eU, eTh and $\mathrm{K}$; (d) radiogenic heat production. EMC, Eastern

Magmatic Centre; WMC,

Western Magmatic Centre.

Black lines are three MT survey lines, numbered with distances $(\mathrm{km})$. ment geochemistry showed high values of uranium around The Rosses in the west of the county, an area not yet covered by AGRS data.

\section{Radiogenic heat production in the Mourne Mountains Complex}

O'Connor (1981) reported that the Palaeogene granites are consistently more radioactive than the Caledonian granites of Ireland. The geology of the Mourne Mountains Complex is described by Cooper and Johnston (2004). The Complex was the focus for uranium exploration in the 1970s and 1980s and more recently the radiochemistry was investigated by Tellus geochemical sampling and AGRS, which mapped enhanced levels of uranium, thorium and potassium. Figure 10.1 shows the geology and ternary images of these three elements for soils and AGRS. Using the AGRS data, Van Dam (2007) calculated the radiogenic heat flux for Northern Ireland using the formula of Carmichael (1989):

$$
\text { heat production }\left(\mu \mathrm{W} \mathrm{m} \mathrm{m}^{-3}\right)=0.337(0.74 \mathrm{eU}+0.199 \mathrm{eTh}+0.26 \mathrm{~K})
$$

where $\mathrm{eU}=$ equivalent uranium concentration in $\mathrm{mg} \mathrm{kg}^{-1}$, eTh $=$ equivalent thorium concentration in $\mathrm{mg} \mathrm{kg}^{-1}$ and $\mathrm{K}=$ potassium concentration in \%. Figure 10.1d shows the calculated radiogenic heat production for the study area with high values of $>4.6 \mu \mathrm{W}$ $\mathrm{m}^{-3}$ over the Mourne Mountains. The Eastern Magmatic Centre (EMC) generally shows higher values than the Western Magmatic Centre (WMC). However, the Tellus survey AGRS underestimates the true radioelement concentration where the gamma radiation from bedrock is attenuated by soil and peat and where erosion has disturbed the equilibrium of the radioactive decay chain. Appleton et al. (2008) compared the AGRS data with soil sample analyses and found that the values of $\mathrm{K}_{2} \mathrm{O}$, eTh and eU measured by AGRS across all Northern Ireland were, respectively, approximately 20\%, 30\% and 66\% less than those measured directly from the soil samples.

Yarr (2013) reported similar findings based on field survey measurements on exposed granite, using a portable gamma-ray spectrometer (PGRS). She calculated average heat production values of $7.79 \mu \mathrm{W} \mathrm{m}$ m $^{-3}$ and $6.56 \mu \mathrm{W} \mathrm{m}^{-3}$ for the eastern and western centres, respectively, comparable with the adjusted AGRS results. Willmot Noller et al. (2015) calculated heat production rates from 3300 new and legacy radioelement analyses across Ireland and found that the Mourne Mountains Complex shows the highest rate of all Irish granites sampled, averaging $6.83 \mu \mathrm{W} \mathrm{m}{ }^{-3}$ from 57 samples. The calculated heat production rates for the Cornish $\left(4.0-5.3 \mu \mathrm{W} \mathrm{m}{ }^{-3}\right)$ and Pennine $\left(3.7-5.2 \mu \mathrm{W} \mathrm{m}^{-3}\right)$ granites are significantly lower.

In 2009 a 600 m deep borehole was drilled into the EMC granite at Silent Valley as part of a Government-funded GSNI research programme into the geothermal energy potential of Northern Ireland (Reay and Kelly, 2010; Fig. 10.2). Continuous rock cores were retrieved and a suite of geophysical measurements was made (Kelly, 2010). A temperature gradient of $21.07^{\circ} \mathrm{C} \mathrm{km}^{-1}$ was calculated, similar to the values recorded in the two earlier 


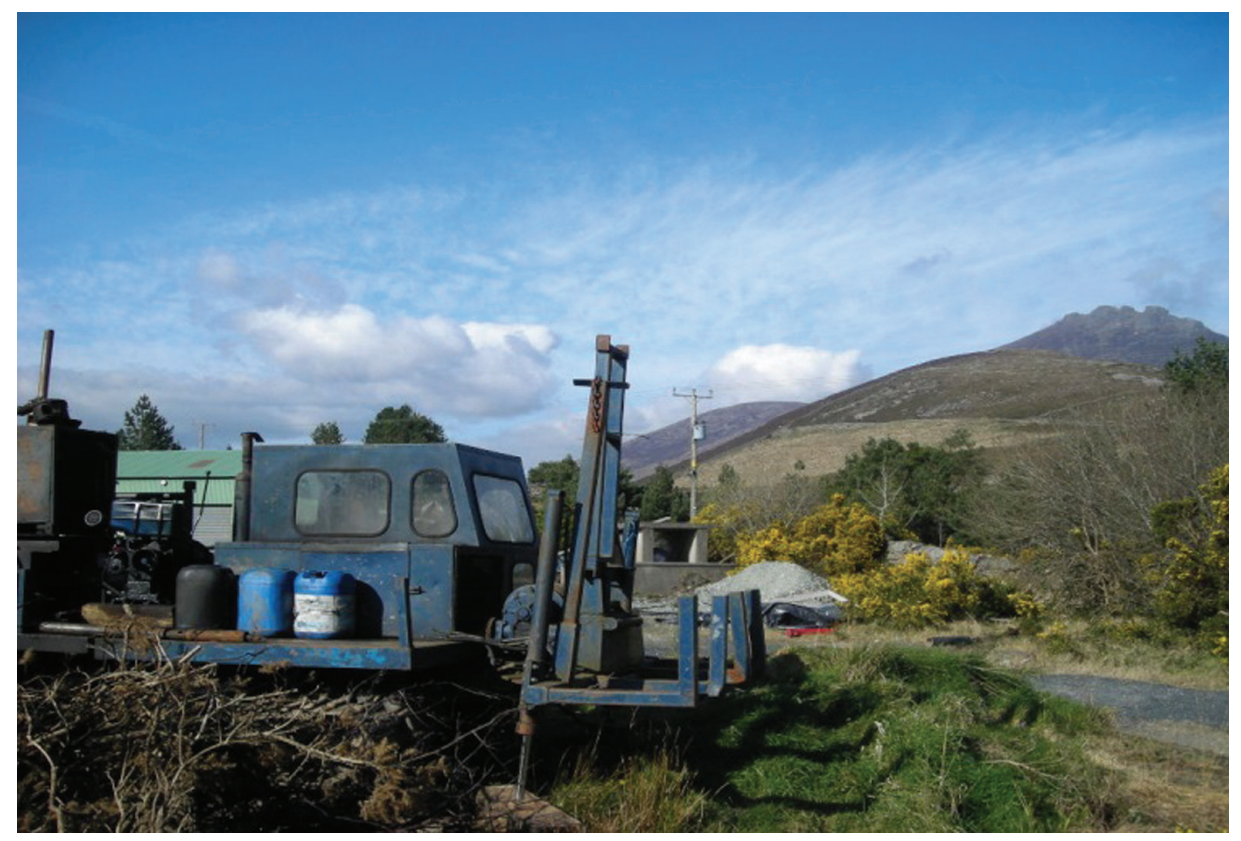

shallow boreholes, but lower than the gradients measured in the Cornish granites. Laboratory measurements of thermal conductivity, density and specific heat capacity were made from granite core samples. Yarr (2013) used the PGRS to measure the radioactivity of the drill-core of the Silent Valley borehole and found that it increased slowly with depth.

\section{Geophysical and structural models of the Mourne Mountains COMPLEX}

The radiometric data and the heat flow calculations discussed above are derived from measurements from the near-surface rocks only. The deep geothermal energy potential will also depend on the geometry (shape, thickness and volume), the bulk geochemistry of the rocks including the water content, the extent of existing fractures at depth and the capacity to enlarge these artificially. During the Tellus Project we investigated some of these using surface geophysical methods.

\section{Features and implications of the gravity and magnetic anomalies}

Variations in the densities of the rocks at depth across an area will be reflected by changes in the gravity anomaly. Relatively higher gravity indicates the presence of denser mafic rocks, while less dense rocks such as granite show lower gravity values. Figure 10.3 shows the variation in gravity across the Mournes; the Palaeogene Slieve Gullion, Carlingford

Figure 10.2. Exploratory drilling in the Eastern Magmatic Centre, Silent Valley, 2009. 


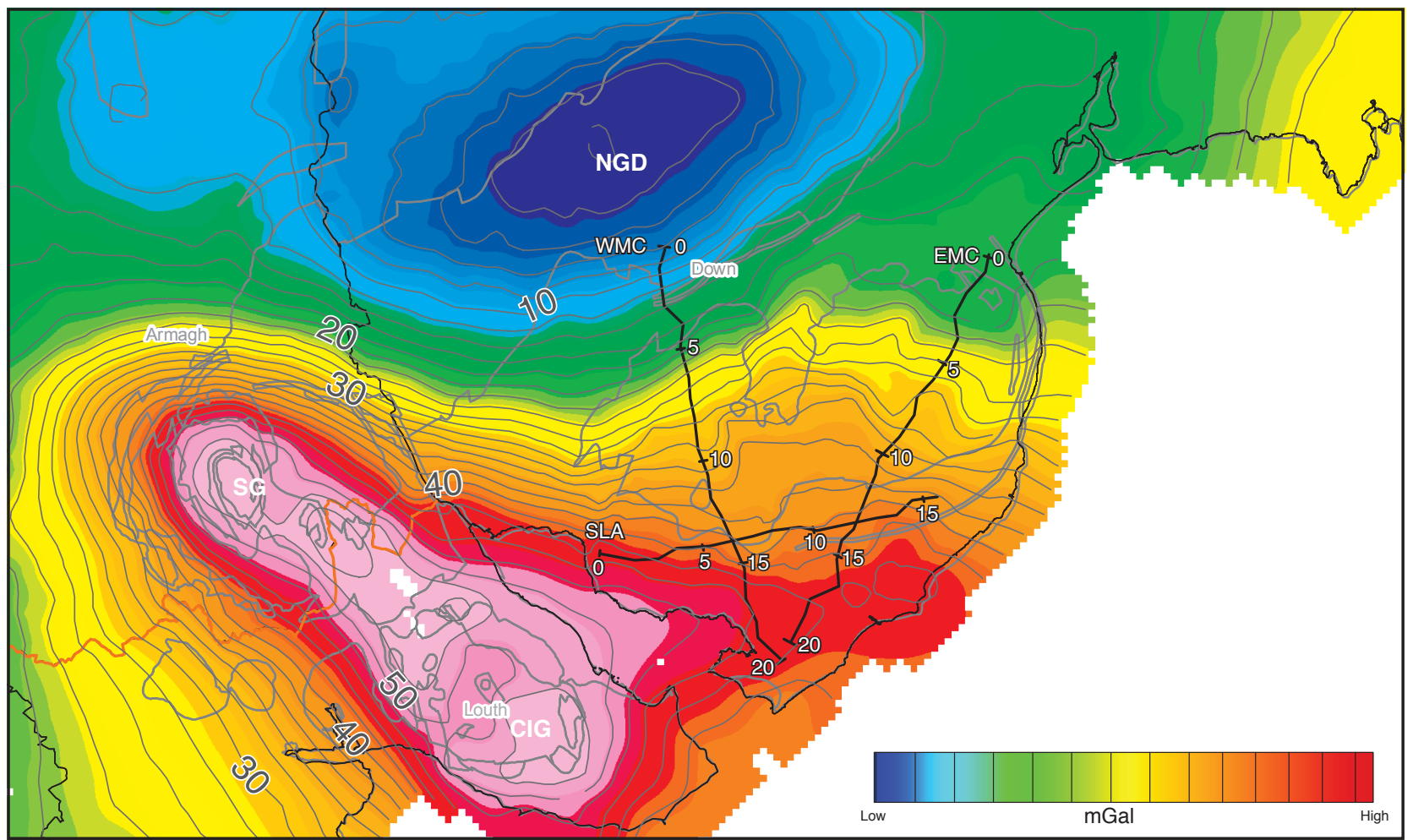

Figure 10.3. Bouguer gravity anomaly map with main geological boundaries superimposed (contour interval: $2 \mathrm{mGal}$. NGD,

Newry Granodiorite Complex; EMC, Eastern Mournes Centre; WMC, Western Mournes Centre; SG, Slieve Gullion Complex; CIG, Carlingford Igneous Centre. and Mournes Igneous complexes are characterised by high positive anomalies untypical of granites. In contrast, the older Devonian Newry Granodiorite to the north shows the low anomaly that would be expected from a large granitic body extending to great depth. The gravity low over the Newry Granodiorite is consistent with a low-density intrusion extending to depths of more than $10 \mathrm{~km}$ and is similar to the anomalies seen over other Caledonian granite batholiths in the Southern Uplands of Scotland.

The gravity field of the north of Ireland was first mapped and modelled by Cook and Murphy (1952). With the benefit of more extensive data, Carruthers et al. (1999) and Reay (2004) presented models that demonstrate that the large positive gravity anomaly across the Gullion/Cooley/Mournes area is caused by a large mafic or ultramafic body underlying the Palaeogene intrusions. An initial 2D model estimated the thickness of the Mournes granite at 2.5 to $4 \mathrm{~km}$, although $2 \mathrm{D}$ modelling overestimates the gravity effect, and thus underestimates the thickness, of a 3D body with the shape of the Mournes Complex. Strong positive gravity anomalies are characteristic of other intrusive centres of the British Palaeogene Igneous Province (Emeleus et al., 2005) and the Skye, Mull, Rum and Blackstone Complexes in the Inner Hebrides have been modelled as cylindrical bodies of mafic or ultramafic composition extending to depths of about $15 \mathrm{~km}$.

Gravity anomaly values decrease from Slieve Gullion and the Carlingford Igneous centre on the Cooley peninsula in a northerly and north-westerly direction towards the 


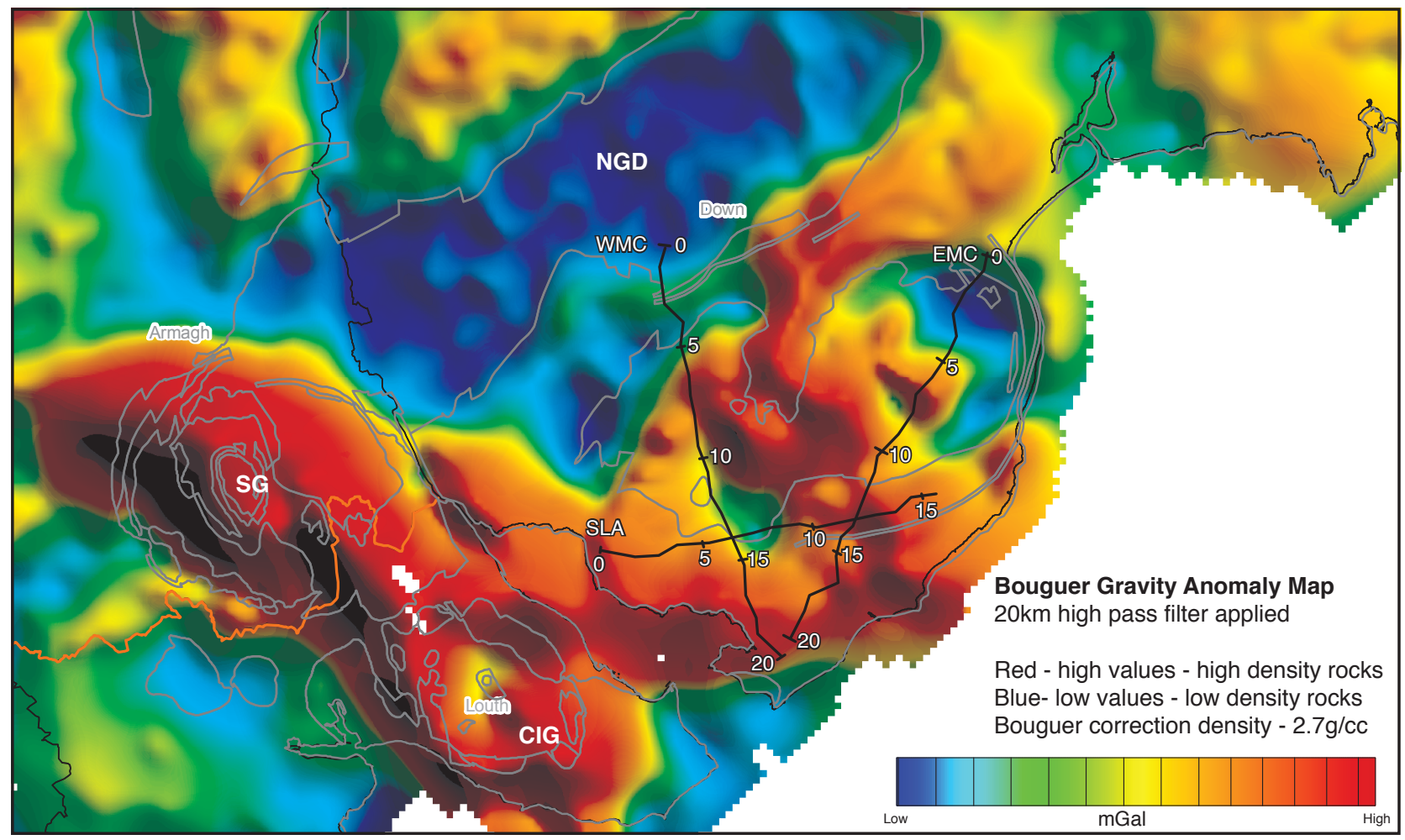

elongate SW-NE gravity low over the Newry Granodiorite. There is no marked change of the gravity gradient across the Mournes, which suggests that the granite intrusions are not very thick, although, when a $20 \mathrm{~km}$ high pass filter is applied to the gravity data (Fig. 10.4), the gravity lows (blue) on the western margin of the WMC and the northeastern margin of the EMC indicate that the low-density granite may be thicker here. It is not immediately obvious from Fig. 10.4 whether the mafic body extends north from the Gullion-Cooley area beneath the entire Mournes granite intrusion, but the anomaly highs (red) suggest that high-density rocks underlie much of the Mournes granite. Three-dimensional (3D) modelling of the gravity anomalies may help to constrain this.

Variations in the magnetic mineral content of rocks can also be mapped by ground or airborne surveys, which may reveal the subsurface extent of igneous intrusions. The Tellus and Tellus Border airborne magnetic data have been merged (Fig. 10.5) and distinctive positive anomalies can be seen to match closely the outcrop pattern of the Slieve Gullion and Carlingford intrusions. In the area of the Mourne Mountains, however, the magnetic anomalies appear to extend south under Carlingford Lough and eastwards slightly offshore. This anomaly pattern indicates that the intrusions may extend beyond the granite outcrop beneath the country rocks. The magnetic data also suggest an asymmetry to the Mournes intrusions, with the anomaly maxima being located just to the south of the WMC and in the eastern part of the EMC.
Figure 10.4. Bouguer gravity anomaly map. $20 \mathrm{~km}$ high pass filter applied. 


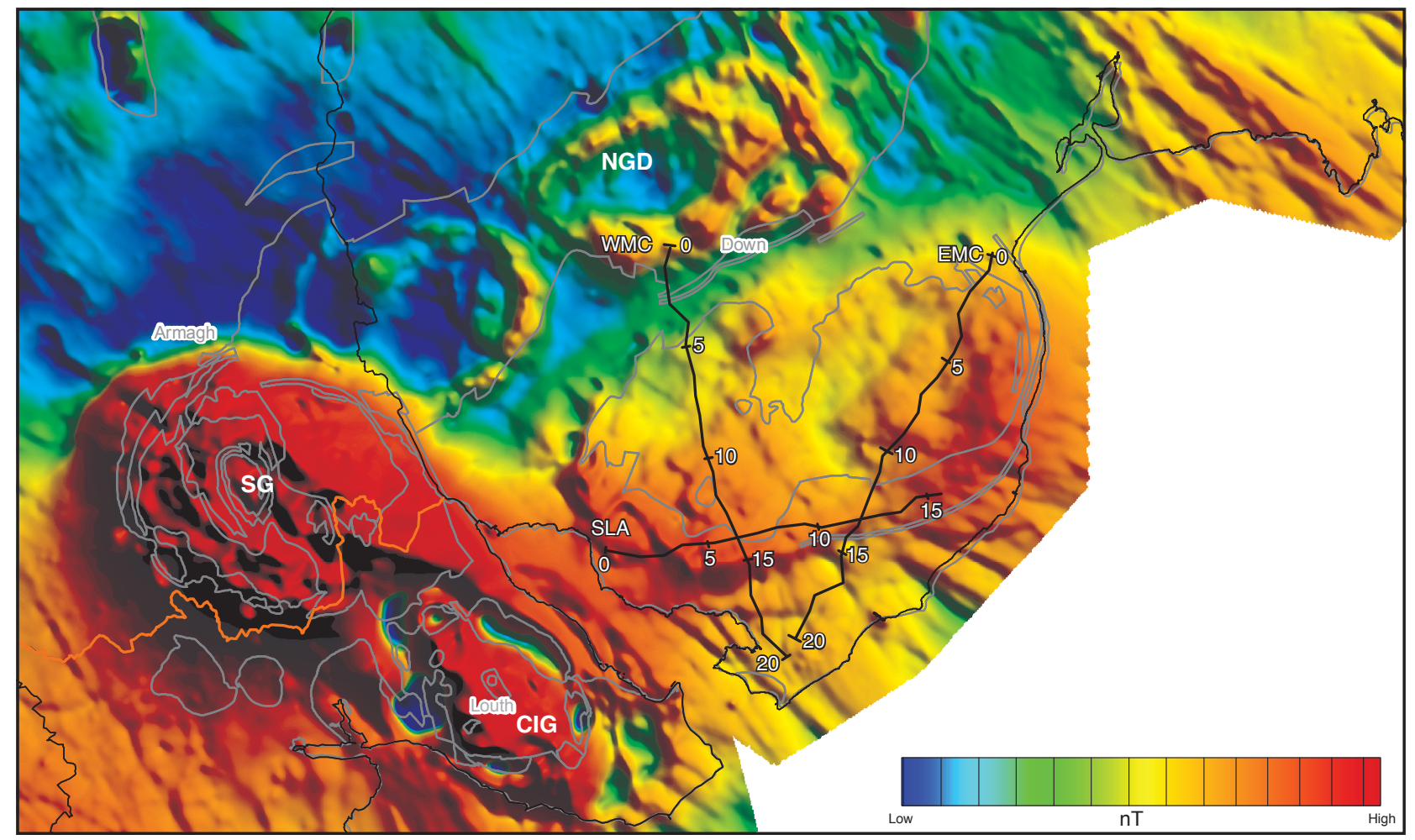

Figure 10.5. South-east County Down and north County Louth: total magnetic intensity anomaly.

\section{Structural models for the emplacement of the Mourne Mountains granites}

Structural studies of the Mourne Mountains have suggested two main mechanisms for the emplacement of the granite intrusion: cauldron subsistence (Richey, 1928) and laccolithic emplacement (Stevenson et al., 2007; Stevenson and Bennett, 2011).

Cauldron subsidence involves a large block of country rock, bounded by a steeply dipping ring dyke, sinking into the underlying magma chamber. Granite magma then rises up the widening 'wall' fissure before moving laterally into a 'roof' fissure using the space created by the sinking country rock. In this passive type of emplacement the magma chamber would be directly below the intrusion. The Richey model proposed that the granite emplacement was asymmetric, with the magma mainly coming up the eastern wall and spreading west to south-westwards into the roof. Steeply dipping mineral fabrics might be expected in the wall zone with shallow dipping or sub-horizontal mineral orientation in the roof zone, and the country rock should show little deformation from the passive intrusion. Walker (1975) proposed a different mechanism involving diapiric ascent of the granite magma, assisted by the upward movement of underlying mafic magma. In this case the granite intrusion was more forceful but the mafic magma chamber was still directly below the granite.

The field evidence for the cauldron subsidence model is not strong and, after reviewing the field mapping by Gibson (1984) and Hood (1981) and studying deformation fabrics 


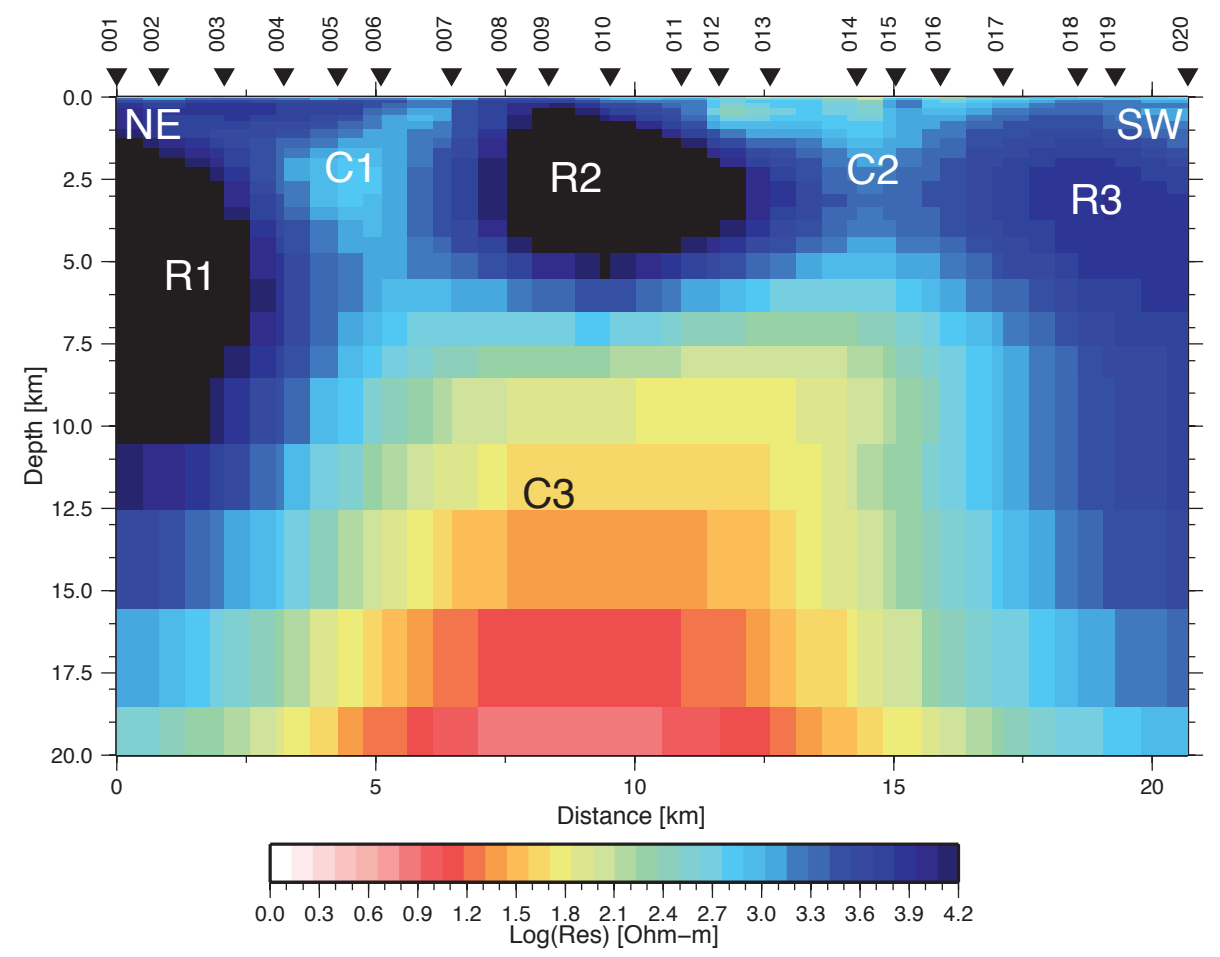

deduced from the anisotropy of magnetic susceptibility, Stevenson and co-workers proposed a new model of emplacement. They proposed that the granitic magma rose from a

Figure 10.6. 2D resistivity model along MT profile EMC.

feeder zone to the south-southwest and was emplaced as a laccolith. The laccolithic model implies a thinner, more lenticular granite body perhaps $2 \mathrm{~km}$ thick and a more forceful emplacement, with deformation of the country rock as observed in places. In this model the granite would be laterally displaced from the underlying mafic magma chamber, as suggested by the gravity data.

\section{Modelling the intrusion dimensions using electromagnetic sounding}

In 2010, in a collaborative field programme, geoscientists from GSNI, DIAS and the University of Birmingham undertook an MT survey to investigate the deep structure of the Mourne Mountains Complex. The operational details and analysis of results are described by Ayres (2011) and Yeomans (2011). Three lines totalling $56 \mathrm{~km}$ were surveyed using Phoenix MT equipment, with MT soundings taken at approximately $1 \mathrm{~km}$ intervals.

The MT data were modelled by joint inversion of the transverse electric and magnetic modes to produce cross-sections beneath the three traverses. For the models in this chapter Ture applied REBOCC inversion software (Siripunvaraporn, 1999) within the band 0.000167 to 22.727 seconds. This produced robust $2 \mathrm{D}$ models of the variation in resistivity of the rocks beneath the profiles that may be interpreted as different rock types. Sedimentary rocks typically have relatively low resistivities whereas dry granites are characterised by high resistivities, although these may be reduced by several orders of 


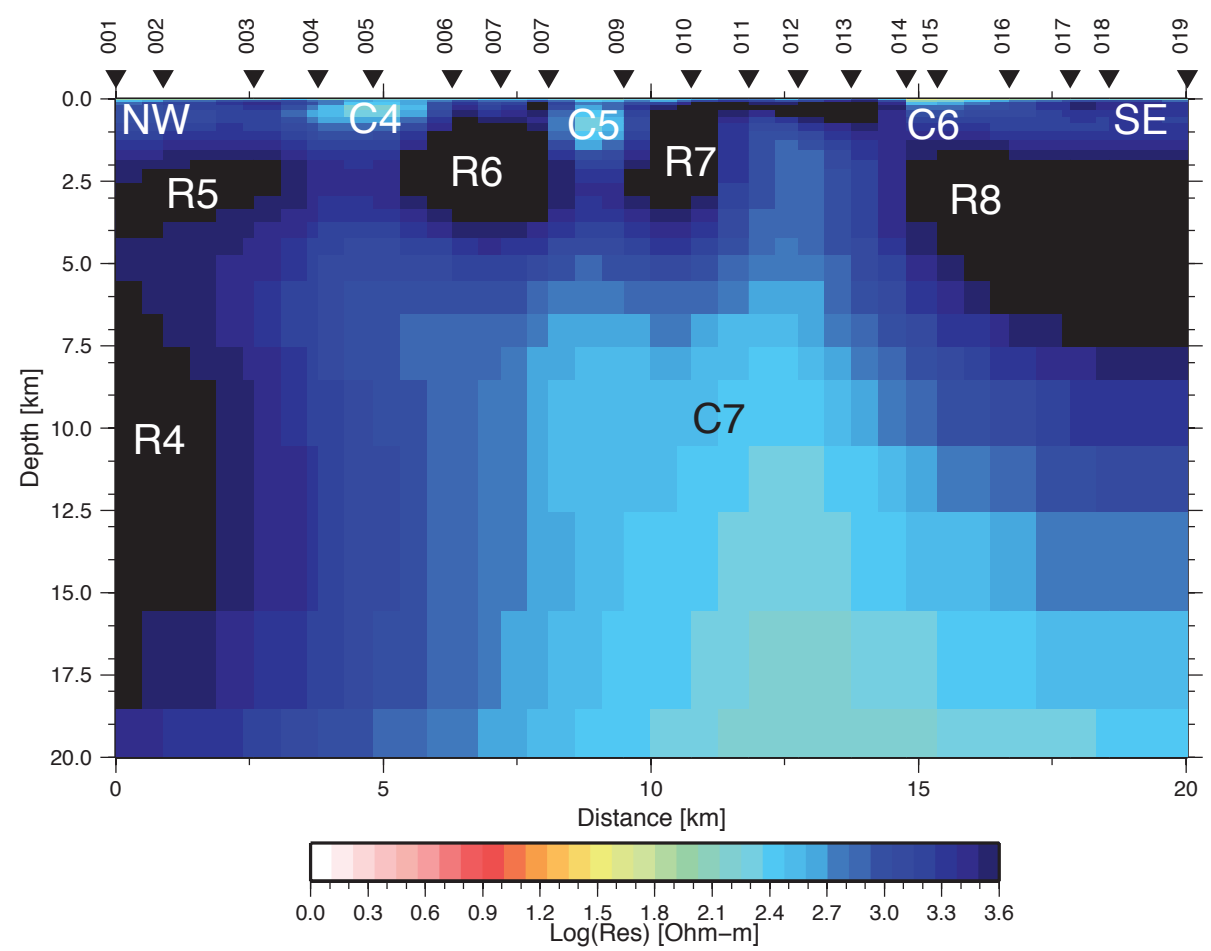

Figure 10.7. 2D resistivity model along MT profile WMC. magnitude if they are fractured or contain even $1 \%$ water. Mafic igneous rocks tend to have much higher resistivities than sedimentary rocks but lower than granite, although water content may again be significant.

The EMC model (Fig. 10.6) shows a near-vertical resistor (R1, with values of $>10,000$ $\Omega \mathrm{m})$ at the northern end of the profile, which reaches a depth of approximately $10 \mathrm{~km}$ and lies north of the granite outcrop. This body could be interpreted as a steeply dipping wall intrusion, consistent with asymmetric intrusion from a feeder zone in the north-east. The near-vertical relatively conductive body ( $\mathrm{C} 1$, values of $<1000 \Omega \mathrm{m}$ ), observed between R1 and the main granite body (R2), may represent a fault zone or a concealed slab of the Silurian greywacke and slate country rock separating different granitic pulses.

The model delineates a large central resistor (R2, values of $>2500$, up to $40,000 \Omega \mathrm{m}$ ), which corresponds to the granite outcrop. $\mathrm{R} 2$ is interpreted as the main granite body of the EMC and extends to depths of 5-6 km. Both R1 and R2 have central zones with electrical resistivities of $>10,000 \Omega \mathrm{m}$, which are typical of relatively dry granites.

At the southern end of the model, where Lower Palaeozoic greywackes crop out, resistor R3 dips at a moderate angle towards the south. R3 is less resistive than R1 and R2 (4000-10,000 $\Omega \mathrm{m}$ ) and it may represent a buried intrusion composed of granite, with higher water content, or of a more mafic lithology. Variations in modelled resistivities may also arise where the same rock types cross the profile at different strike angles (one of the limitations of the 2D MT modelling technique is that a single geological strike angle must be defined for the entire profile, and this strike angle may not be exactly correct everywhere 


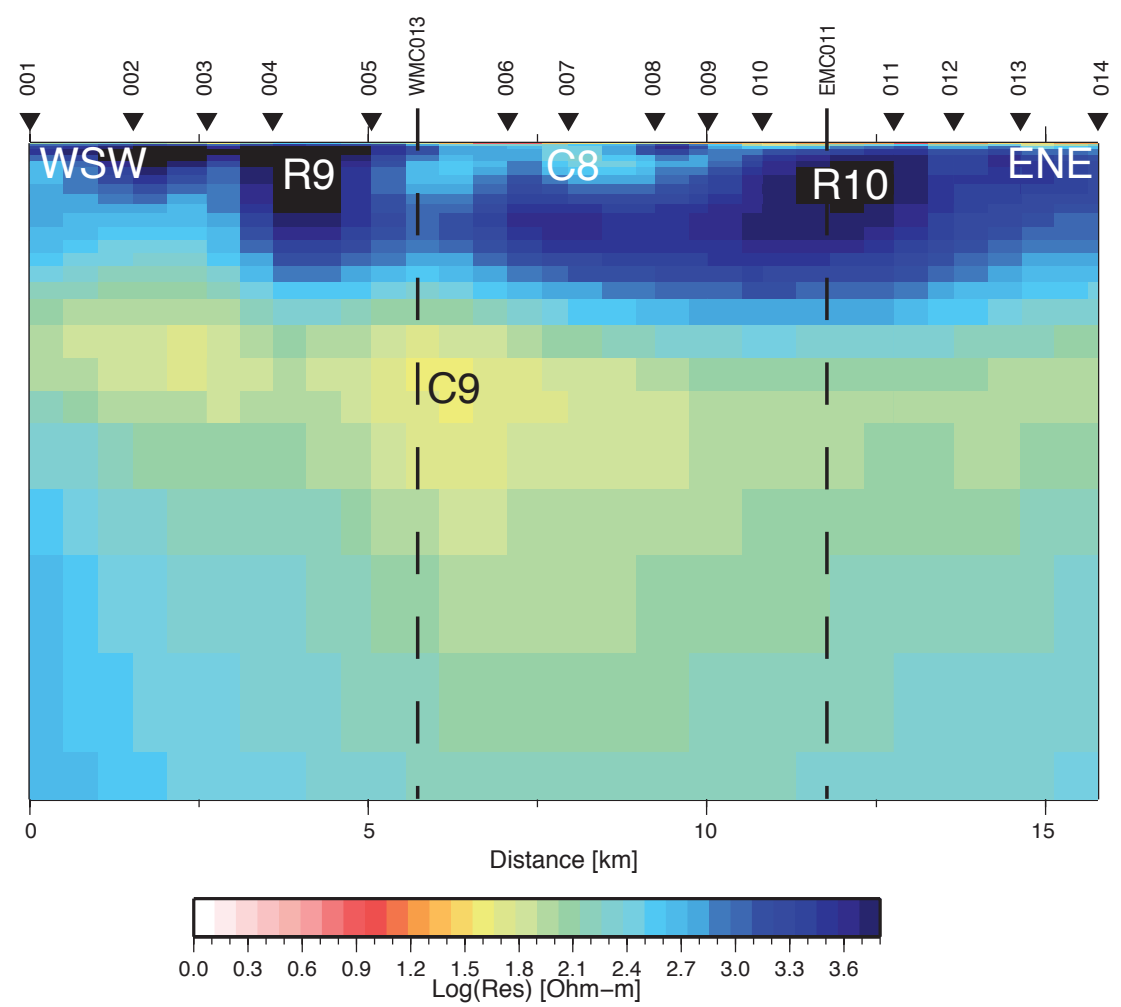

along the profile, potentially leading to inaccuracies in the recovery of resistivity values). The position and dip of R3, to the south of the granite outcrop, could be taken as support for the laccolithic emplacement model but the separation of R3 from the main EMC by a narrow conductive zone and the relatively steep dip of R3 at depth would require some modification of the Stevenson model. Additional MT and gravity modelling work is required to further constrain the geological origin of R3 and assess its geothermal potential.

Conductive body C3 (resistivities of $<100 \Omega \mathrm{m}$ ) at depths of $8 \mathrm{~km}$ to $20 \mathrm{~km}$ beneath the EMC would be consistent with the position of a deep high-density intrusion originally proposed by Cook and Murphy (1952), but the origin of its low resistivity is not known and such values are not typical of mafic igneous rocks. Possible explanations include hydrothermal alteration of mafic rocks beneath the granites; the presence of water-filled fractures; ductile shear zones with highly conductive graphite; or sulphide mineralisation relating to the Mournes magmatism.

The MT model across the WMC (Fig. 10.7) also shows a near-vertical resistor (R4) at its northern end extending to depths of at least $15 \mathrm{~km}$, which may be interpreted as the MT response from the Newry granodiorite which crops out here. Resistors R6 and R7 correspond to most of the outcrop of the WMC and R5 may represent a northward extension of the WMC beneath the country rock. These resistors are relatively shallow (4-5 km maximum depth) and separated by relatively conductive bodies C4 and C5, which may be related to fault zones. South of the granite outcrop, resistor R8, which dips southward from $1 \mathrm{~km}$ to $10 \mathrm{~km}$ depth, could represent a magmatic feeder zone of granite with higher

Figure 10.8. 2D resistivity model along MT profile SLA showing intersections with WMC and EMC profiles. 


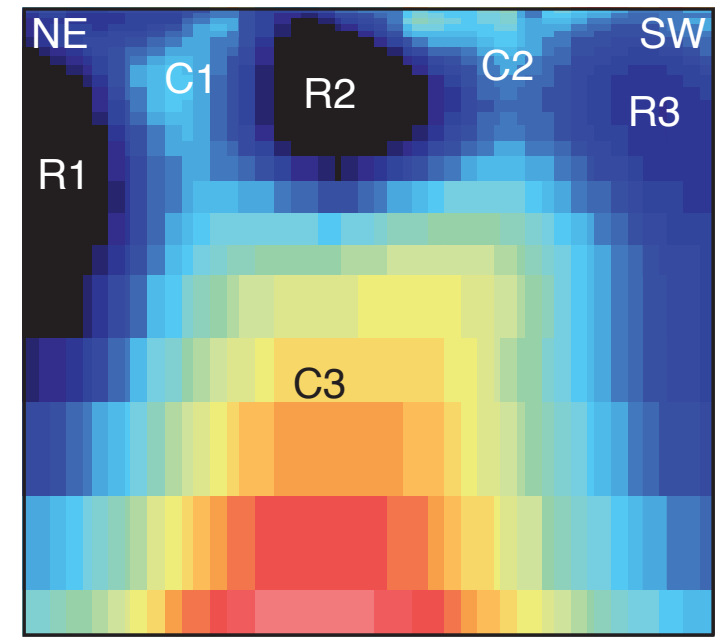

a. This paper

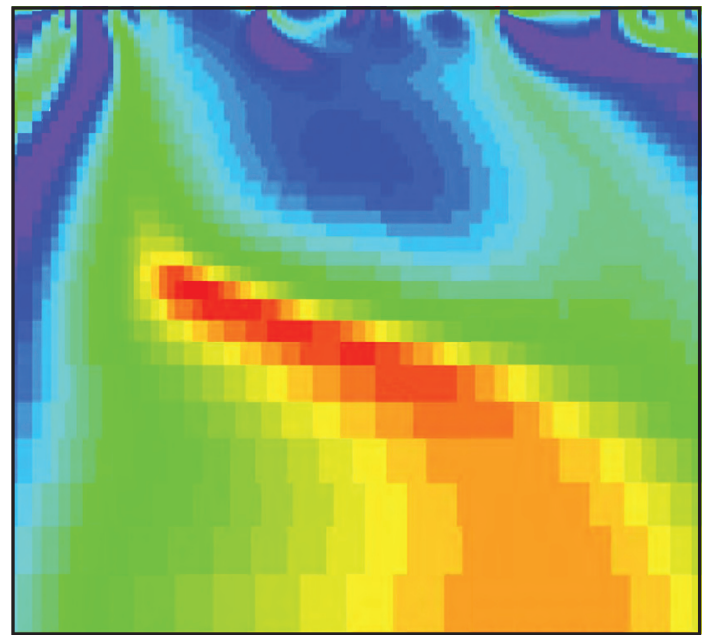

b. Ayres (2011)
Figure 10.9. Comparison of $2 \mathrm{D}$ resistivity models along the EMC MT survey line, produced using different algorithms. Note: horizontal and vertical scales are equal in this figure; in previous model figures the horizontal exaggeration is about 1.5 times the vertical. water content, or more mafic lithologies, similar to R3. Although R3 and R8 have different resistivity values, such a situation can arise where a $2 \mathrm{D}$ resistive body crosses the two profiles at different strike angles. From the result of the model it can be seen that different relatively conductive zones are mapped between resistive granitic bodies. Conductive body C7, lying beneath the southern part of the WMC, is similar to C3 under the EMC but with slightly higher resistivities (100-400 $\Omega \mathrm{m})$.

The model along the profile SLA, which runs just south of the WMC and EMC granite outcrops in a WSW-ENE direction (Fig. 10.8), has two laterally persistent shallower resistors. R9 is interpreted as a southward extension of the G4 granite intrusion concealed beneath the greywackes and with its base at about $4 \mathrm{~km}$ depth. The resistor appears to extend close to the surface, which suggests that the granite is close to the surface and/or that the hornfelsed greywacke outcropping here is also highly resistive where contact metamorphism has reduced its water content. The laterally extensive resistor R10 corresponds to the northern shallower margin of resistors $\mathrm{R} 3$ and $\mathrm{R} 8$, its base rising to $5 \mathrm{~km}$ depth between the WMC and EMC profiles. Together these resistors suggest the presence of an intrusive body concealed beneath the greywackes and dipping south towards Carlingford Lough. Over its western part R11 is overlain by the shallow relatively conductive $\mathrm{C} 8$, which may be interpreted as relatively unaltered greywacke country rock. Conductive body C9, with minimum resistivities of about 40 $\Omega \mathrm{m}$ at about $7 \mathrm{~km}$ depth, lies beneath R10 and R11 and corresponds to the locations of the shallowest parts of $\mathrm{C} 3$ and $\mathrm{C} 7$ on the EMC and WMC profiles respectively.

The MT models suggest that the granites are relatively thin (EMC 5-6 km, WMC 4-5 $\mathrm{km}$ ), although thicker than proposed for the laccolith model and still with some potential as a deep geothermal energy resource. The steeply dipping resistor and conductor at the northern end of the EMC profile may represent the juxtaposition of a granite wall intrusion and a thin slab of water-bearing country rock, which could constitute an attractive EGS target. 
Similarly, the southward-dipping resistor south of the two magmatic centres, if interpreted as a buried granitic intrusion, would be a credible EGS target. However, some caution must be exercised when considering the detailed geometry of the modelled bodies described above.

The inversion of the MT data produced robust deep 2D models that are broadly similar to those produced independently by Yeomans (2011) and Ayres (2011) from the same data, although the modelled 'bodies' differ in details of shape and resistivity values (Fig. 10.9). The differences between the models produced by different modelling algorithms reflect the non-uniqueness of the MT inversion method. This highlights the importance of integrating the use of MT data with other methods such as gravity and magnetic interpretation.

\section{Conclusions}

The Tellus surveys have mapped variations in the radioelement distribution of rocks and soils of the Mourne Mountains Complex. Previous work and recent geochemical ground follow-up of the Tellus data confirm the radiogenic heat potential of these rocks, which are among the most radioactive granites in Ireland. 2D modelling along an MT sounding transect across the WMC suggests that the granite extends down to $4-5 \mathrm{~km}$ depth, which is consistent with the results from $2 \mathrm{D}$ modelling of the gravity data. The results from the MT modelling yielded slightly greater depths of $5-6 \mathrm{~km}$ for the granites of the EMC.

The MT models do not provide clear evidence in favour of either the cauldron subsidence or the laccolith emplacement models of granite intrusion. The steeply dipping resistive body to the north could be interpreted as a wall intrusion of the former whereas the south-dipping resistor in the south could be the feeder zone of the latter. Irrespective of their origin, these deeper bodies could represent EGS targets. The MT models indicate the presence of an unexpected high-conductivity zone beneath the resistive granites. This zone is of unknown origin and is much deeper than current targets but, if indicative of fractured water-bearing rocks, could hold EGS potential in the future. Detailed 3D modelling of the gravity and magnetic anomalies may help to constrain the extent of any underlying mafic intrusion and resolve its relationship to the conductive mass below the Mourne Mountains.

The EGS potential of the Mournes granite remains enigmatic, the measured high heat production values of the granites being very favourable, whereas the complicated gravity signature, moderate heat flow values and modest geothermal gradients are less favourable factors. The thicknesses of the main granite bodies, as interpreted from the MT data, are less than those of other EGS targets in the UK but the steeply dipping resistive zones to the north and south of the granite outcrop may warrant further investigation to confirm their form and shed some light on their origin.

\section{ACKNOWLEDGEMENTS}

MDT publishes with the permission of the Director of the Geological Survey of Ireland. DMR publishes with the permission of the Executive Director of the British Geological Survey (NERC). 


\section{REFERENCES}

Appleton, J.D., Miles, J.C.H., Green, B.M.R. and Larmour, R., 2008 'Pilot study of the application of Tellus airborne radiometric and soil geochemical data for radon mapping', Journal of Environmental Radioactivity, 99, 10, 1687-97. Available at http://nora.nerc.ac.uk/5443/. http://dx.doi.org/10.1016/j.jenvrad.2008.03.011.

Ayres, L., 2011 'Constraints from magnetotellurics on the subsurface structure and emplacement of the Mourne Granites'. Unpublished MSci thesis. University of Birmingham.

Busby, J., 2010 'Geothermal prospects in the United Kingdom'. Proceedings, World Geothermal Congress 2010. Bali, Indonesia. Available at http://nora.nerc.ac.uk/15965/.

Carmichael, R.S. (ed.), 1989 Handbook of Physical Properties of Rocks, Volume 1. Boca Raton, FL. CRC Press.

Carruthers, R.M., Beamish, D., Heaven, R.E., Legg, I.C., Mitchell, W.I., Reay, D.M. and Walker, A.S.D. 1999. Regional Interpretation of Gravity and Aeromagnetic Data from Northern Ireland. GSNI Technical Report 99/1. Belfast.

Cook, A.H. and Murphy, T., 1952 'Measurements of gravity in Ireland north of the line, SligoDundalk'. Geophysical Memoirs, 2, 4. Dublin. Dublin Institute for Advanced Studies. Available at https://www.dias.ie/.

Cooper, M.R. and Johnston, T.P., 2004 'Palaeogene intrusive igneous rocks', in W.I. Mitchell (ed.), The Geology of Northern Ireland: Our Natural Foundation. Second edition, 179-98. Belfast. Geological Survey of Northern Ireland.

Downing, R.A. and Gray, D.A. (eds), 1986 Geothermal Energy - the Potential in the United Kingdom. London. British Geological Survey. HMSO. Available at www.iretherm.ie/documents/.

Emeleus, C.H. and Bell B.R., 2005 British Regional Geology: the Palaeogene Volcanic Districts of Scotland. Fourth edition. Keyworth, UK. British Geological Survey.

Feely, M. and Madden, J.S., 1986 'A quantitative regional gamma-ray survey on the Galway Granite, western Ireland'. In C.J. Andrew et al. (eds), Geology and Genesis of Mineral Deposits in Ireland, 195-200. Dublin. Irish Association for Economic Geology.

Feely, M. and Madden, J.S., 1987 'The spatial distribution of K, U, Th and surface heat production in the Galway Granite, Connemara, western Ireland', Irish Journal of Earth Sciences, 8, 2, $155-64$

Feely, M. and Madden, J.S., 1988 'Trace element variation in the leucogranites within the main Galway Granite, Connemara, Ireland', Mineralogical Magazine, 52, 139-46.

Feely, M., McCabe, E. and Kunzendorf, H., 1991 'The evolution of REE profiles in the Galway Granite Western Ireland'. Irish Journal of Earth Sciences, 11, 1, 71-89.

Gibson, D., 1984 'The petrology and geochemistry of the Western Mourne Granites, Co. Down, N. Ireland', unpublished PhD thesis, Queen's University Belfast.

Goodman, R., Jones, G.L., Kelly, J., Slowey, E. and O’Neill, N., 2004 Geothermal Energy Exploitation in Ireland - Review of the Current Status and Proposals for Optimising Future Utilisation. Final Report to Sustainable Energy Ireland. CSA Report 3085/02.04. Dublin.

Goodman, R.M., Jones, G.L. and Kelly, J.G., 2010 'Methodology in assessment and presentation of low enthalpy geothermal resources in Ireland', in Proceedings, World Geothermal Congress 2010. Bali, Indonesia.

GT Energy, 2011 Response to the Northern Ireland Renewable Heat Incentive: Consultation on the Proposed NI-RHI Support Scheme. Dublin. GT Energy.

Hood, D.N., 1981 'Geochemical, petrological and structural studies on the Tertiary granites and associated rocks of the Eastern Mourne Mountains, County Down, N. Ireland', unpublished PhD thesis, Queen's University Belfast.

Jones, G.L., Goodman, R.M. and Kelly, J.G., 2010 'Low enthalpy geothermal resources of Ireland maps encourage geothermal projects', in Proceedings, World Geothermal Congress 2010. Bali, Indonesia. 
Kelly, J., 2010 Deep Geothermal Exploration Drilling, AES Kilroot Power Station and Silent Valley Reservoir Area. Completion Report. SLR Consulting Ltd for Geological Survey of Northern Ireland, Belfast.

Kelly, J., Goodman, R., Jones, G.L., O’Neill, N. and Pasquali, R., 2005 Geothermal Energy Review of Northern Ireland - Final Report to INTERREG. CSA Report 3194/01.05.

Madden, J.S., 1987 'Gamma-ray spectrometric studies of the main Galway Granite, Connemara, west of Ireland', unpublished PhD thesis, National University of Ireland, Galway.

McCabe, E., 1993 'Radioelement and REE geochemistry of selected late-Caledonian Irish granites', unpublished PhD thesis, National University of Ireland, Galway.

O'Connor, P., 1981 'Radioelement geochemistry of Irish granites', Mineralogical Magazine, 44, 485-95.

Pasquali, R., Allen, A., Burgess, J., Jones G.L. and Hunter Williams, T., 2015 'Geothermal energy utilisation - Ireland country update', in Proceedings, World Geothermal Congress 2015. Melbourne, Australia.

Pasquali, R., O’Neill, N., Reay, D. and Waugh T., 2010 'Geothermal potential of Northern Ireland', in Proceedings, World Geothermal Congress 2010. Bali, Indonesia.

Reay, D., 2004 'Geophysics and concealed geology' in W.I. Mitchell (ed.), The Geology of Northern Ireland: Our Natural Foundation. Second edition, 227-48. Belfast. Geological Survey of Northern Ireland.

Reay, D. and Kelly, J., 2010 'Deep geothermal energy resource potential in Northern Ireland', European Geologist, 29, 14-18.

Richey J., 1928. 'The structural relations of the Mourne Granites (Northern Ireland)', Quarterly Journal of the Geological Society of London, 83, 653-88.

Siripunvaraporn, W., 1999 'An efficient data-subspace two-dimensional magnetotelluric inversion and its application to high resolution profile across the San Andreas Faults at Parkfield California', unpublished $\mathrm{PhD}$ thesis, Oregon State University, Corvallis.

SKM, Sinclair Knight Merz, 2012 Geothermal Energy Potential in Great Britain and Northern Ireland. Report for the Renewable Energy Association. London. Available at www.r-e-a.net/.

Stevenson, C.T.E. and Bennett, N., 2011 'The emplacement of the Palaeogene Mourne Granite Centres, Northern Ireland: new results from the Western Mourne Centre', Journal of the Geological Society, 168, 831-6.

Stevenson, C.T.E., Owens, W.H., Hutton, D.H.W., Hood, D.N. and Meighan, I.G., 2007. 'Laccolithic, as opposed to cauldron subsidence, emplacement of the Eastern Mourne pluton, N. Ireland: evidence from anisotropy of magnetic susceptibility', Journal of the Geological Society, 164, 99-110.

Van Dam, C.L. 2007 Radiogenic Thermal Heat Potential of Northern Ireland. Belfast. Geological Survey of Northern Ireland Technical Report (unpublished).

Walker, G.P.L., 1975 'A new concept of the evolution of the British Tertiary intrusive centres', Journal of the Geological Society, 131, 121-41.

Wheildon, J., Gebski, S. and Thomas-Betts, A., 1985 Further Investigations of the U.K. Heat Flow Field (1981-1984). London. British Geological Survey Technical Report WJ/GE/85/6.

Willmot Noller, N.M., Daly, J.S. and the IRETHERM team, 2015 'The contribution of radiogenic heat production studies to hot dry rock geothermal resource exploration in Ireland', in Proceedings, World Geothermal Congress 2015. Melbourne, Australia.

Yarr, K., 2013 'Assessment of the geothermal potential of the Mourne Granite, County Down', unpublished MSc thesis, University of Newcastle.

Yeomans, C.M., 2011 'Geothermal implications of the Mourne Mountains: constraints from magnetotelluric modelling', unpublished MSci thesis, University of Birmingham. 
Unearthed: impacts of the Tellus surveys of the north of Ireland

First published in 2016 by the

Royal Irish Academy

19 Dawson Street

Dublin 2

www.ria.ie

Copyright (C) 2016 Royal Irish Academy

ISBN: 978-1-908996-88-6

The articles in this book are open access and distributed under the terms of the Creative Commons Attribution 4.0 licence, which permits unrestricted use, distribution and reproduction in any medium, provided the original authors and source are credited. To view a copy of this licence, visit https://creativecommons.org/licenses/by/4.0/

Except where noted:

Geological mapping for Northern Ireland / Tellus data are provided by the Geological Survey of Northern Ireland.

Geological mapping for Ireland / Tellus Border data are provided by the Geological Survey of Ireland.

Topographic mapping for Northern Ireland is derived from Land and Propery Services Open Data and contains public sector information licensed under the Open Government Licence v3.0. (http://www.nationalarchives.gov.uk/doc/open-governmentlicence/version/3/).

Topographic mapping for Ireland is derived from Ordnance Survey of Ireland Open Data (https://creativecommons.org/licenses/by/4.0/legalcode).

While every effort has been made to contact and obtain permission from holders of copyright, if any involuntary infringement of copyright has occurred, sincere apologies are offered, and the owner of such copyright is requested to contact the publisher.

British Library Cataloguing-in-Publication Data. A catalogue record is available from the British Library.

Design: Alex Donald, Geological Survey of Northern Ireland.

Index: Brendan O'Brien.

Printed in Poland by L\&C Printing Group. 


\section{Table of Contents:}

\section{Prelim}

DOI: https://doi.org/10.7486/DRI.b851k323d

\section{Chapter 1}

The Tellus geosciences surveys of the north of Ireland: context, delivery and impacts

DOI: https://doi.org/10.7486/DRI.st74s528d

\section{Chapter 2}

The Tellus airborne geophysical surveys and results DOI: https://doi.org/10.7486/DRI.t148tx96z

\section{Chapter 3}

The Tellus geochemical surveys, results and applications

DOI: https://doi.org/10.7486/DRI.t722wq645

\section{Chapter 4}

Stakeholder engagement for regional geoscientific surveying: the Tellus Border communications campaign

DOI: https://doi.org/10.7486/DRI.w089fr763

\section{Chapter 5}

Mineral resources and Tellus: the essential balance DOI: https://doi.org/10.7486/DRI.wd37kb12s

\section{Chapter 6}

Gold exploration in the north of Ireland: new targets from the Tellus Projects

DOI: https://doi.org/10.7486/DRI.wh24m696v

\section{Chapter 7}

Using soil geochemistry to investigate gold and base metal distribution and dispersal in the glaciated north of Ireland

DOI: https://doi.org/10.7486/DRI.wm11n3806

\section{Chapter 8}

Critical metals for hightechnology applications: mineral exploration potential in the north of Ireland DOI: https://doi.org/10.7486/DRI.wp98p0649

\section{Chapter 9}

A natural laboratory for critical metals investigations in the Mourne Mountains granites

DOI: https://doi.org/10.7486/DRI.cc08ww45f

\section{Chapter 10}

Geothermal potential of granitic rocks of the Mourne Mountains

DOI: https://doi.org/10.7486/DRI.ff36jm09f

\section{Chapter 11}

Shape and intrusion history of the Late Caledonian

Newry Igneous Complex, Northern Ireland

DOI: https://doi.org/10.7486/DRI.2v248822m

\section{Chapter 12}

Using Tellus data to enhance targeting of volcanogenic massive sulphide mineralisation in the Tyrone Igneous Complex

DOI: https://doi.org/10.7486/DRI.5x226w262

\section{Chapter 13}

The geological significance of electrical conductivity anomalies of the Ordovician- Silurian Moffat Shale Group, Northern Ireland

DOI: https://doi.org/10.7486/DRI.6m31f4149

\section{Chapter 14}

Faults, intrusions and flood basalts: the Cenozoic structure of the north of Ireland

DOI: https://doi.org/10.7486/DRI.90205h306

\section{Chapter 15}

Information for agriculture from regional geochemical surveys: the example of soil $\mathrm{pH}$ in the Tellus and Tellus Border data

DOI: https://doi.org/10.7486/DRI.dv14c8060

\section{Chapter 16}

An ecohydrological investigation of wetlands in the border counties of Ireland: a framework for a holistic understanding of wetland systems DOI: https://doi.org/10.7486/DRI.hd775d90j 
Chapter 17

Assessing nutrient enrichment risk to groundwaterdependent ecosystems in the border counties of Ireland DOI: https://doi.org/10.7486/DRI.k356pk18j

\section{Chapter 18}

Mapping the terrestrial gamma radiation dose

DOI: https://doi.org/10.7486/DRI.k930rb86z

\section{Chapter 19}

Soils and their radiometric characteristics

DOI: https://doi.org/10.7486/DRI.mp495t62g

\section{Chapter 20}

Modelling in-house radon potential using Tellus data and geology to supplement inhouse radon measurements

DOI: https://doi.org/10.7486/DRI.ns06hm86z

\section{Chapter 21}

Determining geochemical threshold values from the Tellus data sets: the examples of zinc and iodine| DOI: https://doi.org/10.7486/DRI.r2087418g

\section{Chapter 22}

Identification of the geochemical signatures of diffuse pollution in the Tellus Border soil data set, using source apportionment

DOI: https://doi.org/10.7486/DRI.wh24m698d

\section{Chapter 23}

Stream sediment background concentrations in mineralised catchments in Northern Ireland: assessment of 'pressures' on water bodies in fulfilment of Water Framework Directive objectives DOI: https://doi.org/10.7486/DRI.x633tf86g

\section{Chapter 24}

Mapping metallic contamination of soils in the Lower Foyle catchment

DOI: https://doi.org/10.7486/DRI.9k42bv355

\section{Chapter 25}

Refining the human health risk assessment process in Northern Ireland through the use of oral bioaccessibility data

DOI: https://doi.org/10.7486/DRI.9p29cr199

\section{Chapter 26}

Combining environmental and medical data sets to explore potential associations between environmental factors and health: policy implications for human health risk assessments

DOI: https://doi.org/10.7486/DRI.9s16dn03n

\section{Chapter 27}

Mapping a waste disposal site using Tellus airborne geophysical data

DOI: https://doi.org/10.7486/DRI.9w03fh87q

\section{Chapter 28}

The use of aero-magnetics to enhance a numerical groundwater model of the Lagan Valley aquifer, Northern Ireland

DOI: https://doi.org/10.7486/DRI.9z90gd711

\section{Chapter 29}

Carbon sequestration in the soils of Northern Ireland: potential based on mineralogical controls DOI: https://doi.org/10.7486/DRI.b277h9556

\section{Chapter 30}

Spatial distribution of soil geochemistry in geoforensics DOI: https://doi.org/10.7486/DRI.b564j6392

\section{End matter}

DOI: https://doi.org/10.7486/DRI.bc38m007j 